Correction

\title{
Correction: Bedon, C.; Fasan, M. Reliability of Field Experiments, Analytical Methods and Pedestrian's Perception Scales for the Vibration Serviceability Assessment of an In-Service Glass Walkway. Appl. Sci. 2019, 9, 1936
}

\author{
Chiara Bedon * (D) and Marco Fasan (D) \\ Department of Engineering and Architecture, University of Trieste, 34127 Trieste, Italy; mfasan@units.it \\ * Correspondence: chiara.bedon@dia.units.it; Tel.: +39-040-558-3837
}

Received: 16 August 2019; Accepted: 26 January 2020; Published: 4 February 2020

check for updates

We, the authors, wish to make the following corrections to our paper [1]

In Section 2.2 of the research paper Appl. Sci. 2019, 9, 1936; https://doi.org/10.3390/app9091936, the authors recall the fundamental aspects of structural dynamics for pedestrian systems, with special attention given to the analysis of Human Structure Interaction (HSI) effects.

In doing so, however, a misspelled equation of motion was described in Equation (1), with the expression:

$$
M \ddot{x}(t)+C(t)+K x(t)=P(t)
$$

where $M, C$, and $K$ represent the modal mass, damping, and stiffness matrices, respectively, $P(t)$ is the imposed external (periodic) force reproducing the motion of occupants, and $x(t)$ is the vertical displacement vector.

The correct, well-known equation of motion —-that replaces the original Equation (1) - is the following:

$$
M \ddot{x}(t)+C \dot{x}(t)+K x(t)=P(t)
$$

The authors apologize for the mistake.

\section{Reference}

1. Bedon, C.; Fasan, M. Reliability of Field Experiments, Analytical Methods and Pedestrian's Perception Scales for the Vibration Serviceability Assessment of an In-Service Glass Walkway. Appl. Sci. 2019, 9, 1936. [CrossRef]

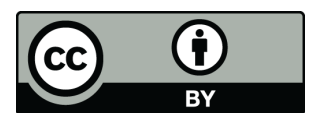

(C) 2020 by the authors. Licensee MDPI, Basel, Switzerland. This article is an open access article distributed under the terms and conditions of the Creative Commons Attribution (CC BY) license (http://creativecommons.org/licenses/by/4.0/). 